\title{
Education for Prevention of Alcohol and Tobacco Consumption in Secondary Education in Cubal
}

\author{
Adelino Pena Calei ${ }^{1}$, Augusto José Fazenda ${ }^{1 *}$ \\ ${ }^{I}$ Natural Sciences Department. Higher Institute of Education Sciences of Kwanza Sul. Katyavala Bwila \\ University. Sumbe. Angola. \\ *Corresponding author: ajfazenda@yahoo.com.br
}

\begin{abstract}
The objective of the study was to characterize the current situation of alcohol and tobacco consumption in secondary school, with a view to the health education, in Cubal, Benguela province, Angola. The study was carried out in the first and second trimester of the school year and the survey to the teacher and student, interviews with school principals and participant's observation during class and in the playground were used as methods. The sample was taken from the Fist Cycle of Secondary Education at "Kilamba" School and it concluded that teachers and students presented themselves to classes after comsuming alcohol and used to consume tobacco during break time in the court-yard. Although teachers and students were aware of the negative effect of alcohol and tobacco consumption, it was noticed that the problem at issue was not systematically addressed in the teaching-learning process of Geography, which would contribute to the prevention of alcohol and tobacco consumption in school and in general life of the citizen.
\end{abstract}

Keywords: Education; Health Education; prevention; alcohol and tobacco; Secondary Education.

\section{Introduction}

All over the world there are many studies focused on the prevention of alcohol and tobacco consumption in school (Vieira et al, 2008; Strauch et al, 2008; Barreto et al, 2010; Moreno, et al 2010; Andrade et al, 2012; Muñino et al, 2013; Malta et al, 2014; Eliker et al, 2015; Varona et al, 2015), however, it is rare for teachers and students to approach this practice at the same time due to the influence made on others and also on the family and the community.

In Angola, the Basic Law of the Education and Teaching System (Law $n^{\circ}$ 17/16 of October 7) states that "Education is a planned and systematized process of teaching and learning, which aims to prepare the individual fully for the requirements of individual and collective life ". The mentioned Law emphasizes that the individual develops in human coexistence in order to be able to face the main challenges of society, especially in the consolidation of peace, national unity, promotion and protection of the rights of mankind as well as in the process of scientific, technical, technological, economic and cultural development of the Country.

The prevention is the antecipation of the hazard in order to avoid the damage, hence the importance of education is to prevent the consumption of alcohol and tobacco in school, it helps people to understand the damages that the use of drugs, whether legal or illegal, bring to life and strives to minimize them.

The consumption of tobacco is considered a chronic additive disorder that in $80 \%$ starts before 20 years of age, and is killed due to the addiction that produces nicotine and whose main clinical manifestations are cardiovascular disorders, respiratory disorders, such as, chronic obstructive pulmonary disease, chronic bronchitis, emphysema and cancer and onset of tumors in several locations (Mendieta, 2017). Prevention of tobacco consumption contributes to the reduction of the prevalence of diseases such as cancer, strokes, and myocardial infarction, in addition to respiratory diseases in general (Figueiredo and Ribeiro, 2011). 
Alcohol abuse is considered a serious public health problem that entails damage to both, psychological, social, familiar and economic levels, regardless of the social, cultural, financial class to which the individual belongs or in which stage of life, as well as the consequences of a variety of problems for the community, such as, the great increase in traffic accidents and deaths, unsafe sexual life, increased self-extermination, increased domestic violence, increased divorce and some types of crime and homicides (Freitas, 2014).

The consumption of alcohol and tobacco develops aggressive behaviors in the school context that can take the form of disruptive attitudes and actions such as failure to comply with norms of behavior, disobedience in school tasks, ways of behaving or dressing that may be considered aggressive, inadequate vocabulary and blackmail or coercion (Muñino et al, 2013). Alcohol and tobacco are the drugs that kill the most in the world; their frequent use causes social, psychic and biological damages, as well as implications for the future life of consummers. (Eliker et al, 2015)

The Prevention develops as a transversal axis of the teaching - learning process that evidences the relationship between society and nature and the interrelations between teacher and student, school-family-community, that is why it is included in environmental education and constitutes a theme of education for health.

In Chapter 36 of diary 21, the Environmental Education was defined as a "process that aims to create a world population that is conscious and concerned about the environment and the problems that concern it, a people who have the knowledge, skills, state of mind, motivation and sense of participation and commitment that enable them to work individually and collectively to solve current problems and prevent them from repeating themselves".

Health education is an educational activity designed to increase the population's knowledge about health and to develop the understanding and personal skills that promote health (Torres, 2013). This is a pedagogical concept oriented to improve the population's way of life, and refers to the possibilities of learning consciously, created with a view of facilitating changes of conduct directed towards a predetermined goal, strictly linked to prevention of the disease, as a means susceptible to modify the behaviors identified as a risk factor for certain diseases.

The National Plan for Health Development (PNDS) in Angola identified the main risks for non-communicable cardiovascular diseases (NCDs), which are: tobacco, unhealthy diet, sedentary lifestyle and excessive consumption of alcohol associated with obesity, hypertension and dyslipidemias. To minimize the negative effects of tobacco consumption it was approved the Law that prohibits smoking in public places, Public Administration services and bodies, shopping centers, supermarkets, hospitals, health centers, showrooms, nurseries, airports, ports, open and closed sports facilities, restaurants, bakeries, hotels, nightclubs and public transport, including taxis.

The above-mentioned Law complements the arranged Framework Convention of the World Health Organization's for the Tobacco Control, establishing rules for the prevention of smoking, in the protection of unintentional exposure to tobacco smoke, regulation of the composition of tobacco products, regulation of the information to be provided on tobacco products, packaging and labeling, health awareness and education, prohibition of advertising in favor of tobacco products, promotion and sponsorship, demand reduction measures related to dependency and cessation of consumption, sale to minors and via automatic means, in order to contribute to reducing the risks or adverse effects that tobacco produces to the health of individuals. 
The promotion and protection of the rights of the person and the environment have been identified as one of the main challenges of society, and, in that direction, the Constitution of the Republic of Angola mentions the fundamental tasks of the Angolan State which are: the creation of the necessary conditions to make effective the economic, social, and cultural rights of citizens, the promotion of well-being, social solidarity and raising the life quality of the angolan people.

For the realization of the rights en-shrined in the Constitution of the Republic requires a citizen capable of participating consciously and actively in raising to its life quality, in this sense, the process of teaching-learning Geography contributes to the integral education of the individual.

The specific objectives of the education and teaching of the First Cycle of Secondary Education stated the following: to deepen on the foundations of a humanistic culture, based on the moral, ethical, civic and patriotic values; to create individual and group work habits and to favor the development of attitudes of methodical reflection and adaptation to change, develop habits, skills, and attitudes for active life and the spirit of initiative, creativity and autonomy.

Torres (2013) refers to creativity and states that a creative student must be an active constructor of his knowledge, be committed to his own learning, to use with flexibility his knowledge and experiences, have good, deep and varied interests, be able to reflect in a personalized way about their contexts of actions and about themselves to project towards the future, have an active, transformative attitude towards learning, make decisions independently and have an adequate self-esteem.

This requires a learning environment that strengthens the self-esteem of teachers and students, where freedom, love, respect and acceptance are promoted. Hence, the importance of education to prevent the consumption of alcohol and tobacco that is harmful to the good learning environment in school.

\section{Research Methodology}

The study has as a sample teachers and students of the "Kilamba" School of the First Cycle of Secondary Education, in Cubal, Benguela province, Angola. Teachers whose age ranges from 27 to 47 years are found at the height of the pleasures of life experimenting, so on the one hand the consumption of alcohol and tobacco appears as a source of pleasure, on the other serves as a life disappointments refuge.

Students range in age from 14 to 17 years, the age group corresponding to adolescence, in which the human being is characterized by biological, cognitive, emotional and social changes. Adolescence is the most vulnerable stage of life for drug experimentation and abuse. It is an important moment for adopting new practices, behaviors and gaining autonomy. The adolescent, stimulated by the intense transformations, becomes more vulnerable to behaviors that can weaken his health, such as, inadequate feeding, sedentary lifestyle, smoking, alcohol consumption and other drugs.

The survey of teachers and students was constructed with questions of simple yes and no and other semi-structured questions that allowed obtaining the information about the knowledge that the sample had on the effects of the consumption of alcohol and tobacco and their opinions on what to do as educational activities for prevention. The interview with the directors allowed obtaining the information of their knowledge about the existence, in the school, of teachers and students to make use of alcohol and tobacco. Through participant's 
observation, was made a triangulation of gathered information, through the surveys and interviews on the consumption of alcohol and tobacco by teachers and students at school.

\section{Discussion}

Location of the "Kilamba" School of the First Cycle of Secondary Education.

The municipality of Cubal has an area of $6,151 \mathrm{~km}^{2}$ and occupies $10.93 \%$ of the territory of the Benguela Province, has a dry tropical climate with desert influences from the West and is limited to the North with the municipalities of Bocoio and Balombo, to the South with the municipalities of Chongoroi and Caluquembe, to the East with the municipality of Ganda and to the West with the municipality of Caimbambo.

Regarding the relief, in the Eastern part predominates mountains and some depressions whereas in the South predominates hills and plateaus. The vegetation of the North and East is rich and in the West part is poor. The hydrography of the municipality consists of the following water network: Coporolo River, Cubal of Ganda River, Cubal of Hanha River, Halu River, Jamba River and Catumbela River.

From the administrative point of view, the municipality of Cubal is divided in four communities which are: headquarters community, Tumbulo, Yambala and Capupa. The municipality of Cubal is inhabited by four ethnic groups: the vahanhas, the ovimbundos or vanano, the vabocoio and the ovimbali. The main activity of Cubal people is agriculture and live-stock.

The "Kilamba" School of the First Cycle of Sencudary Education is located in the municipality of Cubal, at an altitude of 640 meters in relation to the average sea level. It is located in the district of Camunda that has as an approximate limit, to the north with the district of Kalohala, to the south with the Cubal River, to the east with the center of the city and to the west with the nascent district.

Framing the theme of education for prevention in the content of Geography in the 9th grade, the general objectives of Geography of the 9th grade in the First Cycle of Secondary Education, which are related to the subject under study in the do-main of knowledge, skills and attitudes of the student, are in the program of the discipline. In the do-main of knowledge the student must express an understanding of the general characteristics of the natural and social environment that surrounds him and recognize that socio-economic development is only possible with the progressive elimination of differences related to well-being and to life quality.

In the do-main of skills the student must participate through the search and presentation of fundamental solutions for the resolution of spatial problems; develop independent study by working autonomously to deepen and explain the concepts of physical and geographic phenomena and socio-economic phenomena.

In the do-main of attitudes the student must demonstrate a spirit of tolerance and capacity for critical dialogue, to value the nature work and the positive action of man on it; develop responsive behavior towards population and environmental problems, be interested in improving the life quality of the population, associating it with the enhancement of the natural and cultural heritage, reveal habits of democratic coexistence, intervene in solving concrete problems of the community in which it is inserted, properly framed in support schemes.

As can be understood, the individual who consumes alcohol and tobacco will hardly fulfill the objectives stated in the First Cycle of Secondary Education and, therefore, will have 
difficulties to reach an integral formation of his personality, as stipulated in the Basic Law of Education and Teaching.

The analysis of the general objectives of the discipline of Geography in the First cycle of Secondary Education allowed understanding its gradual derivation from the general objectives of Education and teaching in Angola. The general objectives of Geography teaching in 9th grade are that students should be able to become aware of the importance of tolerance and respect for other people and cultures, to aware that well-being and the life quality are indispensable constraints for development, recognize that development can only be achieved with the progressive suppression of contrasts concerning the life quality, to manifest attitudes of responsibility in the pursuit of natural and cultural heritage.

Education for the prevention of alcohol and tobacco consumption falls within the content of Geography, in the 9th class in Theme 2 - Africa: its population, the mobility of people and spatial contrasts. The subject in question is developed in sub-theme 2.4. The well-being and life quality of the African population. This content is contained in the summary 2.4.1. Health problems and the promotion of health services. This topic addresses the endemic diseases and contagious infectious diseases, highlighting the need for education to prevent alcohol and tobacco consumption. Health education is a cross-cutting issue, so the teacher should take advantage of all favorable contexts to address this issue with students.

As a methodological suggestion, declared in the 9th-grade Geography teaching program, the teacher should relate the concept of well-being to that of life quality and highlight other causes of health problems, namely hygiene and sanitary deficiency, derisory budgets for primary health care programs, scarce and dispersed hospital network, few health professionals and degraded health infrastructure, among others.

Survey results given to teachers and students

The 10 teachers interviewed are between 25 and 50 years old. Of the total, 9 teachers corresponding to $92 \%$ are males and 1 that is $8 \%$, female.About alcohol consumption, 6 teachers who represented the $60 \%$ answered that they consume alcohol, while 4 that corresponded to $40 \%$ denied the consumption of this drug. About tobacco consumption of the 10 teachers in question, 5 which represented the $50 \%$ answered that they consumed and 5 responded that they did not consume tobacco. Data obtained indicated that most teachers consume alcohol and tobacco. These numbers compared to the total number of school and county teachers explain the need of education for prevention at school.

The teachers stated that they are aware of the danger of consuming alcohol and tobacco, which cause lung diseases, delinquency, school drop-out, liver diseases and difficulties of assimilation, hence the importance of education for prevention. Regarding the behavior of teachers who used to consume alcoholic beverages, the respondents answered that they were often absent from work or on the premises. Regarding alcohol and tobacco education for prevention, the teachers presented the need for the promotion of lectures and debates to raise students' awareness of the danger of alcohol and tobacco consumption.

In the study, 50 students from the 9th class were aged between 14 and 17 years of age, of whom 46 were males, representing the $92 \%$ of the sample and 4 females, representing the $8 \%$. Regarding tobacco consumption, 50 students surveyed completed $100 \%$ of the sample, 30 students representing the $60 \%$ answered that they consumed, while 20 students who corresponded to $40 \%$ denied the consumption of tobacco. Although the percentage of those who do not consume tobacco is significant, the ideal would be to avoid tobacco consumption because in addition to being detrimental to individual and collective health, it also causes 
financial expenses that are reflected in the family`s economy. The percentage of school students who used to consume tobacco is high, hence Education for prevention to avoid the consequences of using this drug in life.

Regarding the consumption of alcohol, of the 50 students in question, 29 used to consume alcoholic beverages that correspond to $58 \%$ and 21 that represened $42 \%$ of the sample denied the use of this drug but assume that they know colleagues in the classes that consume alcoholic beverages, which confirms the results expressed by those who declared consumption of alcoholic beverages. The data indicated that the number of students consuming alcohol is high and with it the possible consequences in the future on the family, professional and social aspects.

Respondent students answered that alcohol and tobacco consumption lead to lung disease, anaemia, and delinquency. As educational activities to raise students' awareness about alcohol and tobacco consumption, they responded favorably to the lectures and debates.

Results of the interview with the General Director and assistant director

The interview conducted with the General Director and the assistant director of education allowed obtaining information about the existence of teachers and students who sometimes used to appear drunk and used to consume tobacco in school. Regarding the behavior of teachers and students who consumed alcohol and tobacco, the interviewed directors mentioned their colleagues' disrespect and their absence at work was frequent. Because of the need of educational activities for the prevention of alcohol and tobacco consumption at school, the directors indicated the lectures, debates and training.

Results of the participant's observation

The author's experience as a teacher at the "Kilamba" school of the First Cycle of Secondary Education allowed the corroboration of the data obtained by surveys and interviews when observing the existence of teachers and students who used to present themselves drunk in class and used to consume tobacco in the yard.

\section{Conclusions}

The study made it possible to determine the existence of teachers and students who sometimes used to appear drunk and used to consume tobacco at school.

The teachers and students responses to the survey showed that they know the negative effect of alcohol and tobacco consumption, but the education for prevention does not systematically develop in the contents of Geography in the 9th grade.In the context of Education for the prevention of alcohol and tobacco consumption, educational activities are being carried out in the "Kilamba" School of the First Cycle of Secondary Education in Cubal, which are being analyzed for their systematization in similar schools.

\section{References}

1. Andrade AG, Anthony JC, Silveira CM. Álcool e suas consequências: uma abordagem multiconceitual. Barueri, SP: Minha Editora, 2009. Available at: http://www.cisa.org.br/artigo/440/livro-alcool-suas-consequencias-uma-abordagem.php 
2. Andrade, S. et al (2012). Relação entre violência física, consumo de álcool e outras drogas e bullying entre adolescentes escolares brasileiros. Available at:

https://www.scielosp.org/scielo.php?pid=S0102311X2012000900011\&script=sci_artte xt\&tlng=es

3. Angola. Lei Base do Sistema de Educação e Ensino. 2016

4. Barreto, S. et al (2010). Exposição ao tabagismo entre escolares no Brasil. ABRASCO. Rio de Janeiro. Brasil. Available at: https://www.scielosp.org/pdf/csc/2010.v15suppl2/3027-3034/pt

5. Capítulo 36 da Agenda 21. Conferência das Nações Unidas para o Ambiente e o Desenvolvimento. Available at: http://portal.mec.gov.br/seb/arquivos/pdf/c36a21.pdf

6. Constituição da República de Angola. 2010. Available at: http://www.wipo.int/wipolex/en/text.jsp?file_id=409390

7. Eliker, E. et al (2015). Uso de álcool, tabaco e outras drogas por adolescentes escolares de Porto Velho - RO, Brasil. Programa de Pós-graduação em saúde colectiva da Universidade Luterana do Brasil, Canoas, RS. Epidemiol. Serv. Saúde, Brasilia, 24 (3): 399-410, jul-set 2015. Available at: https://www.scielosp.org/pdf/ress/2015.v24n3/399410/pt

8. Figueiredo, C. and Ribeiro, E. (2011). Transtornos Mentais Comuns. Tabagismo. Consumo de bebida alcoólica. Coordenação de Epidemiologia e Informação. Secretaria Municipal de Saúde. São Paulo. Brasil. Available at: http://www.perfeitura.sp.gov.br/saude/publicaçõesceinfo

9. Freitas, J. O. (2014). Revisão da literatura sobre impacto causado pelo abuso de álcool em uma comunidade da estratégia da saúde da família. Trabalho de conclusão do curso de especialização em atenção básica em saúde da família. Universidade Federal de Minas Gerais. Brasil. Available at: https://www.nescon.medicina.ufmg.br/biblioteca/imagem/6370.pdf

10. Malta, DC et al (2014). Consumo de álcol entre adolescentes brasileiros segundo a Pesquisa Nacional de Saúde Escolar (PeNSE 2012). Rev Bras EPIDEMIOL. SUPPL.PeNSE 2014; 203-214. Available at: http://www.scielo.br/pdf/rbepid/v17s1/pt_1415-790X-rbepid-17-s1-00203.pdf

11. Mendieta, Y. 2017. Prevención del uso de tabaco, drogas y alcohol. Comisión Nacional para el control de los productos de tabaco. República de Panamá. Available at: http://www.minsa.gob.pa/sites/default/files/general/rotafolio_-v-_final.pdf

12. Moreno, RS, Ventura, RN, Brêtas, JR. (2010). The use of alcohol and tobacco by adolescents in the municipality of Embu, São Paulo, Brazil. Available at: http://www.scielo.br/pdf/reeusp/v44n4/en_16.pdf

13. Muñino, M. et al. 2013. Violencia escolar y consumo de alcohol y tabaco en adolescentes de Educación Secundaria. European Journal of Investigation in Health, Psychology ab Educatión, 2013, vol. 3 nº 2 (pags 137-147). Available at: dialnet.unirioja.es/descarga/articulo/4519062.pdf

14. Plano Nacional de Desenvolvimento Sanitário. Volume 2. Angola. Available at: https://www.mindbank.info/item/3460

15. Strauch, ES et al (2008). Uso de alcool por adolescents: estudo de base populacional. Rev Saúde Pública 2009:43 (4): 647-55 Available at: www.scielo.br/pdf/rsp/v43n4/329.pdf 
16. Torres, M. (2013) Promoción de la salud en sistemas educativos. Vol. 1. Instituto Pedagógico Latinoamericano y Caribeño, IPLAC. Universidad de Ciencias Pedagógicas Enrique José Varona (UCP EJV). Ministerio de Educación. Cuba.

17. Varona, M. et al (2015). Estrategia educativa antitabáquica para estudiantes de Tecnologia de salud de Camaguey. Humanidades Médicas 2015;15(2):262-282 Available at: www.humanidadesmedicas.sld.cu/index.php/hm/article/

18. Vieira, PC et al (2008). Uso de álcool, tabaco e outras drogas por adolescentes escolares em município do Sul do Brasil. Cad. Saúde Pública, Rio de Janeiro, 24(11):2487-2498, nov. 2008 Available at: https://www.scielosp.org/pdf/csp/2008.v24n11/2487-2498/pt

19. WHO. Framework Convention on Tobacco Control: guidelines for implantation Article 5.3;Article 8; Articles 9 and 10; Article 11; Article 12; Article 13; Article $14-$ 2013 edition. ISBN 978924150518 5. Available at: https://apps.who.int/iris/bitstream/handle/10665/80510/9789241505185_eng.pdf;sequ $\underline{\text { ence }=1}$ 